\title{
ANALISIS KARAKTERISTIK KONSUMEN BERAS DI KECAMATAN PEKANBARU KOTA KOTA PEKANBARU
}

\author{
${ }^{1)}$ Asgami Putri \\ 1) Staff Pangajar Fakultas Pertanian Universitas Lancang Kuning \\ Email : putriasgami@yahoo.co.id
}

\begin{abstract}
ABSTRAK
Penelitian ini bertujuan mengetahui karakteristik konsumen yang membeli beras baik beras unggul nasional maupun beras unggul lokal.

Penelitian ini dilaksanakan di Kecamatan Pekanbaru Kota, Kota Pekanbaru.Sampel yang diambil sebanyak 120 orang. Metode penelitian yanng digunakan adalah accidental sampling. Pengumpulan data dilakukan dengan wawancara. Analisis yang digunakan dalam penelitian adalah analisis deskriptif.

Karakteristik konsumen yang mengkonsumsi beras unggul nasional memiliki rata-rata umur 41 tahun, memiliki pendapatan rata-rata Rp.1.679.333,-, pekerjaan Ibu rumah tangga, memiliki tanggungan keluarga sebanyak 3 orang, memiliki pendidikan terakhir Diploma. Sedangkan karakteristik konsumen yang mengkonsumsi beras unggul lokal antara lain memiliki umur rata-rata 35 tahun, memiliki tanggngan keluarga sebanyak 3 orang, memiliki pendapatan keluarga sebanyak Rp. 3.274.638,-, memiliki pendidikan terakhir yaitu sarjana. Jenis beras unggul lokal yang banyak dikonsumsi adalah beras anak daro dan beras belida, sedangkan beras unggul nasional yang dikonsumsi adalah kuriak kusuik.
\end{abstract}

Keywords : Analisis Karakteristik Konsumen, Konsumen, Beras.

\section{PENDAHULUAN}

Beras adalah komoditas pangan pokok yang dikonsumsi oleh sebagian besar penduduk Indonesia. Konsumen yang membeli beras tidak tergantung hanya pria ibu rumah tangga saja tetapi seluruh masyarakat Indonesia adalah konsumen beras. Hal ini terjadi karena beras merupakan makanan pokok masyarakat Indonesia.

Beras dipilih menjadi pangan pokok karena sumber daya alam lingkungan mendukung penyediaannya dalam jumlah yang cukup, mudah dan, cepat pengolahannya, memberi kenikmatan pada saat menyantap, dan aman dari segi kesehatan. Sesungguhnya rasa lapar dapat dipuaskan dengan memakan makanan apa saja, terutama makanan sumber pati atau lazimnya disebut karbohidrat. Namun perlu diperhatikan, dalam konsep makan, terdapat dua unsur yang dianut oleh kebanyakan orang yaitu kenyang dan nikmat.

37 Analisis Karakteristik Konsumen Beras Di Kecamatan Pekanbaru Kota Kota Pekanbaru 
Beras yang ada di Indonesia dibagi atas dua yaitu beras unggul nasional dan beras unggul lokal. Beras unggul nasional lebih banyak dibudidayakan oleh petani,sedangkan beras unggul lokal hanya bisa dibudidayakan ditempat-tempat tertentu saja. Tetapi ternyata konsumsi untuk kedua jenis beras ini banyak juga tidak hanya untuk beras unggul nasional maupun untuk beras unggul lokal. Jenis beras unggul nasional yang dibudidayakan di Indonesia antara lain Ciherang (bisa mencapai $47 \%$ dari total varietas yang ditanam), IR-64, Mekongga, Cimelati, Cibogo, Cisadane, Situ Patenggang, Cigeulis, Ciliwung, Membramo, Sintanur, Jati luhur, Fatmawati, Situbagendit, Inpari (Inbrid Padi Irigasi). Misalnya: Inpari 1-10, Inpari 11, Inpari 12 dan Inpari 13, Cilosari, Diahsuci, Bestari, Inpari Sidenuk, Pandan Putri varietas Inpari, sedangkan untuk beras unggul lokal yang dibudidayakan di Indonesia adalah Beras 42, Beras Mundam Pulau, Beras Sokan Biasa, Beras Sokan Putih, Beras Sokan Kuriak (Beras SKM), Menthik Susu Beras Jepang asal Magelang, Menthik Wangi Bentuknya mirip dengan pandan wangi yang bulat. Namun warna sedikit kusam dan berasnya beraroma wangi. Karena kandungan gulanya lebih rendah, jenis beras organik ini dapat mengontrol gula dalam darah, Beureum Sengit Varietas lokal asal Cianjur, Pandan Wangi Beras asal Cianjur, Rojolele, Ramos, dll.

Konsumen merupakan individu ataupun kelompok yang berusaha untuk memenuhi ataupun mendapatkan barang atau jasa untuk kehidupan pribadi ataupun kelompoknya. Menurut Undang-Undang Republik Indonesia No.8 tahun 1999 tentang perlindungan konsumen mendefinisikan bahwa konsumen itu adalah setiap orang pemakai barang dan jasa yang tersedia dalam masyarakat, baik dalam memenuhi kepentingan pribadi, kelompok, keluarga, orang lain, maupun makhluk hidup lainnya dan tidak untuk diperdagangkan. karakteristik konsumen juga berguna untuk mengetahui segmentasi pasar yang dapat dibagi dalam empat kategori yaitu demografi, perilaku, profil, psikografi dan karakteristik kepribadian. Ukuran demografi konsumen terdiri dari umur, jenis kelamin, pendapatan, agama, status perkawinan, pendidikan, etika, dan kebangsaan.

Tujuan dari penelitian ini adalah untuk mengetahui karakteristik konsumen yang mengkonsumsi beras unggul nasional dan karakteristik beras unggul lokal.

38 Analisis Karakteristik Konsumen Beras Di Kecamatan Pekanbaru Kota Kota Pekanbaru 


\section{METODE PENELITIAN}

Penelitian ini dilaksanakan menggunakan metode survey penelitian dilaksanakan di Kecamatan Pekanbaru Kota. Penelitian ini dilaksanakan selama enam bulan yang dimulai pada bulan Agustus 2013 sampai dengan bulan Februari 2014.

Data diambil dengan menggunakan metode convenience sampling / accidental sampling. Dalam penelitian jumlah responden yang dijadikan sampel sebanyak 120 rumah tangga dengan rincian 105 rumah tangga yang mengkonsumsi beras unggul lokal dan 15 rumah tangga mengkonsumsi beras unggul nasional.

Data yang diperlukan dalam penelitian ini adalah data primer dan data sekunder. Dimana data primer diperoleh dari hasil wawancara dari para konsumen atau yang disebut responden dalam penelitian ini. Data tersebut diperoleh dengan cara membagikan kuisioner yang dibagikan kepada para konsumen. Analisis yang digunakan dalam menetukan karakteristik konsumen beras adalah dengan analisis statistik deskriptif. Data dapat diperoleh dengan cara mewawancarai konsumen secara langsung dengan menggunakan kuisioner data yang akan diperoleh mengenai karakteristik konsumen ini adalah jenis kelamin, umur, tingkat pendidikan, jumlah tanggungan keluarga, tingkat pendapatandan lain-lain.

\section{HASIL DAN PEMBAHASAN}

Karakteristik konsumen dapat dilihat dari usia, jenis kelamin, suku bangsa,status pernikahan, jumlah anggota rumah tangga, pendidikan terakhir, pekerjaan responden, pekerjaan pasangan, dan pendapatan rata-rata keluarga per bulan. Dalam penelitian ini karakteristik konsumen dapat membantu dalam menentukan ciri-ciri konsumen yang mengkonsumsi beras baik beras unggul nasional maupun unggul lokal. Dengan hal ini kita dapat memberikan sebuah masukan atau saran beras apa yang disukai oleh konsumen. Berikut ini penjelasan karakteristik konsumen dalam peneltian ini:

Usia konsumen yang dimaksud adalah usia atau umur seseorang yang dijadikan responden dalam penelitian ini. Umur konsumen yang dijadikan responden yang mengkonsumsi beras unggul lokal adalah 35 tahun dapat dilihat

39 Analisis Karakteristik Konsumen Beras Di Kecamatan Pekanbaru Kota Kota Pekanbaru 
pada Lampiran 3, sedangkan rata-rata umur responden yang mengkonsumsi beras unggul nasional 41 tahun. Dari umur ini kita mengetahui bahwa ternyata yang menyukai beras unggul lokal adalah rata-rata umur 35 tahun. Umur responden ini adalah umur yang matang dan dapat memutuskan sesuatu dengan baik. Jumlah konsumen yang berumur 31-40 tahun yang mengkonsumsi beras unggul sebanyak 45 orang $(42,86 \%)$ dan yang mengkonsumsi beras unggul nasional sebanyak 7 orang konsumen $(46,67 \%)$. Konsumen yang mengkonsumsi beras unggul lokal yang memiliki usia berkisar antara 21-30 tahun sebanyak 20 orang (19.05\%) sedangkan untuk beras unggul nasional konsumen yang mengkonsumsi beras unggul nasional dengan rentang umur yang sama sebanyak 4 orang (26.67\%). Rentang umur berikutnya yaitu rentang umur 41-45tahun dimana yang mengkonsumsi beras unggul lokal sebanyak 16 orang $(15,23 \%)$ sedangkan yang mengkonsumsi beras ungguul nasional sebanyak 4 orang $(26,67 \%)$.

Tabel 1. Karakteristik Konsumen Berdasarkan Usia

\begin{tabular}{|l|l|l|l|l|l|}
\hline No & Usia & \multicolumn{2}{|c|}{ Jumlah (Org) } & \multicolumn{2}{c|}{ Persentase (\%) } \\
\cline { 3 - 6 } & & $\begin{array}{l}\text { Var. Unggul } \\
\text { Lokal }\end{array}$ & $\begin{array}{l}\text { Var. Unggul } \\
\text { Nasional }\end{array}$ & $\begin{array}{l}\text { Var. Unggul } \\
\text { Lokal }\end{array}$ & $\begin{array}{l}\text { Var. Unggul } \\
\text { Nasional }\end{array}$ \\
\hline 1 & $15-20$ tahun & 11 & 0 & 10.48 & 0 \\
\hline 2 & $21-30$ tahun & 20 & 0 & 19,05 & 0 \\
\hline 3 & $31-40$ tahun & 45 & 7 & 42.86 & 46.67 \\
\hline 4 & $41-45$ tahun & 16 & 4 & 15.23 & 26.67 \\
\hline 5 & $>45$ tahun & 13 & 4 & 12,38 & 26.67 \\
\hline & Jumlah & 105 & 15 & 100 & 100 \\
\hline
\end{tabular}

Hampir seluruh responden berjenis kelamin perempuanbaik responden yang mengkonsumsi beras unggul lokal maupun yang mengkonsumsi beras unggul nasional. Untuk responden penelitian yang mengkonsumsi beras unggul lokal sebanyak 63 orang $(60 \%)$ dan yang untuk beras unggul nasional sebanyak 15 responden $(100 \%)$. Hal ini dikarenakan pengambilan data sebagian besar dilakukan pagi sampai sore hari dimana sebagian besar laki-laki sedang bekerja. Sehingga pada saat dilakukan tanya jawab untuk mengambil data yang ada dirumah ketika itu adalah rsponden perempuan. Selain itu, data ini menunjukkan bahwa pengambil keputusan mengenai konsumsi beras sampai saat ini masih didominasi oleh perempuan. 
Tabel 2. Karakteristik Konsumen Berdasarkan Jenis Kelamin

\begin{tabular}{|l|l|l|l|l|l|}
\hline No & $\begin{array}{l}\text { Jenis } \\
\text { Kelamin }\end{array}$ & $\begin{array}{c}\text { Var. Unggul } \\
\text { Lokal }\end{array}$ & $\begin{array}{c}\text { Var. Unggul } \\
\text { Nasional }\end{array}$ & $\begin{array}{c}\text { Var. Unggul } \\
\text { Lokal }\end{array}$ & $\begin{array}{c}\text { Var. Unggul } \\
\text { Nasional }\end{array}$ \\
\hline 1 & Laki-Laki & 42 & 0 & 40 & 0 \\
\hline 2 & Perempuan & 63 & 15 & 60 & 100 \\
\hline & Jumlah & 105 & 15 & 100 & 100 \\
\hline
\end{tabular}

Kota Pekanbaru sebagai Ibukota Provinsi Riau memiliki keanekaragaman suku yang mendiami kota Pekanbaru. Suku yang ada antara lain suku melayu sebagai masyarakat tempatan dan ada juga suku yang merupakan pendatang antara lain suku minang, suku jawa, suku batak dan suku tionghoa. Sehingga Kota Pekanbaru kaya akan budaya yang berasal dari suku pendatang tersebut. Dalam penelitian ini suku minang merupakan suku yang mendominasi penelitian ini sebanyak 49 orang $(46,67 \%)$ yang mengkonsumsi beras unggul lokal, sedangkan suku terbanyak yang mengkonsumsi beras unggul nasional adalah suku minang yatu sebanyak 7 orang (46.67\%).

Hal ini dapat dipahami karena penelitian ini berlokasi di Pekanbaru dimana sebagian besar penduduknya didominasi oleh suku Minang yang merupakan pendatang di Kota Pekanbaru.Ini dikarenakan suku melayu memang suku lokal di Kota Pekanbaru tetapi memang lebih banyak suku pendatang terutama suku minang. Suku yang juga tergolong banyak dalam penelitian ini yang mengkonsumsi beras unggul lokal adalah suku melayu (23.33 persen), sedangkan suku yang kedua terbanyak dalam mengkonsumsi beras unggul nasional yaitu suku jawa sebanyak 5 orang (33.33\%). Sedanngkan suku tionghoa dan suku batak dalam penelitian ini tidak menyukai beras unggul nasional.

Hal ini dssebabkan karena baik beras unggul lokal maupun beras unggul nasional memiliki segmen pasarnya seperti contohnya beras unggul lokal memiliki variasi rasa beras sama juga dengan beras unggul nasional dimana beras ungul nasional juga memiliki rasa pera dan rasa pulen tetapi tetap lebih banyak yang mengkonsumsi beras unggul lokal karenan rasanya lebih disukai dibandingkan dengan rasa beras unggul nasional. Untuk lebih jelasnya dapat dilihat pada Tabel 3 .

41 Analisis Karakteristik Konsumen Beras Di Kecamatan Pekanbaru Kota Kota Pekanbaru 
Tabel 3. Karakteristik Konsumen Berdasarkan Suku

\begin{tabular}{|l|l|l|c|c|c|}
\hline \multirow{2}{*}{ No } & Suku & \multicolumn{2}{|c|}{ Jumlah (Org) } & \multicolumn{2}{c|}{ Persentase (\%) } \\
\cline { 3 - 6 } & $\begin{array}{l}\text { Var. Unggul } \\
\text { Lokal }\end{array}$ & $\begin{array}{l}\text { Var. Unggul } \\
\text { Nasional }\end{array}$ & $\begin{array}{l}\text { Var. Unggul } \\
\text { Lokal }\end{array}$ & $\begin{array}{l}\text { Var. Unggul } \\
\text { Nasional }\end{array}$ \\
\hline 1 & Melayu & 18 & 3 & 17,14 & 20 \\
\hline 2 & Minang & 49 & 7 & 46.67 & 46.67 \\
\hline 3 & Tionghoa & 7 & 0 & 6.67 & 0 \\
\hline 4 & Batak & 16 & 0 & 15,24 & 0 \\
\hline 5 & Jawa & 15 & 5 & 14,24 & 33.33 \\
\hline & Jumlah & 105 & 15 & 100 & 100 \\
\hline
\end{tabular}

Jumlah tanggungan keluarga dalam penelitian ini sebagian besar berjumlah antara 2 sampai 3 orang dalam rumah tangga. Untuk responden yang memiliki tanggungan keluarga yang terbanyak yaitu 64 rumah tangga (60.95\%)berjumlah 2-3 orang anggota keluarga yang mengkonsumsi beras unggul lokal sedangkan yang mengkonsumsi beras unggul nasional sebanyak 5anggota keluarga (33.33\%), dan yang terbanyak selanjutnya yaitu lebih dari 4 orang anggota keluarga yaitu sebanyak 24 rumah tangga (22,86\%) yang mengkonsumsi beras unggul lokal sedangkan yang mengkonsumsi beras unggul nasional 7 rumah tangga (46,67\%) dan yang terkecil adalah 0-1 anggota keluarga yaitu sebanyak 17 rumah tangga (16.19 persen). Dari data ini diketahui bahwa sebagian rumah tangga yang ada di Pekanbaru rata-rata yang mengkonsumsi beras unggul lokal memiliki anggota keluarga sebanyak 3 orang anggota keluarga, sedangkan ratarata yang mengkonsumsi beras unggul nasional memiliki tanggungan keluarga sebanyak 3 orang anggota kelurga.

Tabel 4: Karakteristik Konsumsen Berdasarkan Jumlah Tanggungan Keluarga

\begin{tabular}{|c|c|c|c|c|c|}
\hline \multirow[t]{2}{*}{ No } & \multirow{2}{*}{$\begin{array}{c}\text { Jumlah } \\
\text { Tanggungan } \\
\text { Keluarga }\end{array}$} & \multicolumn{2}{|c|}{ Jumlah (Org) } & \multicolumn{2}{|c|}{ Persentase } \\
\hline & & $\begin{array}{l}\text { Var. Unggul } \\
\text { Lokal }\end{array}$ & $\begin{array}{c}\text { Var. Unggul } \\
\text { Nasional }\end{array}$ & $\begin{array}{l}\text { Var. Unggul } \\
\text { Lokal }\end{array}$ & $\begin{array}{c}\text { Var. Unggul } \\
\text { Nasional }\end{array}$ \\
\hline 1 & $0-1$ org & 17 & 3 & 16.19 & 20 \\
\hline 2 & $2-3$ org & 64 & 5 & 60.95 & 33,33 \\
\hline 3 & $>=4$ org & 24 & 7 & 22.86 & 46.67 \\
\hline & Jumlah & 105 & 15 & 100 & 100 \\
\hline
\end{tabular}

Hasil penelitian menunjukkan bahwa tingkat pendidikan terakhir responden yang mengkonsumsi beras unggul lokal yang ada di Pekanbaru terbanyak adalah SMA sebanyak 35 orang responden (33.33\%) dan yang

42 Analisis Karakteristik Konsumen Beras Di Kecamatan Pekanbaru Kota Kota Pekanbaru 
mengkonsumsi beras unggul nasional sebanyak 4 orang (26,67\%), S1 sebanyak 30 orang responden (25 persen), SLTPsebanyak 19 orang $(15,83 \%)$ mengkonsunsi beras unggul lokal, sedangkan yang mengkonsumsi beras unggul nasional sebanyak 5 orang (33.33\%), pendidikan terakhir dari responden yang mengkonsumsi beras unggul lokal dari jenjang pendidikan SD yang sebanyak 7 orang (6.67\%), pendidikan Diploma yang mengkonsumsi beras unggul lokal sebanyak 9 orang $(8.57 \%)$, dan yang mengknsumsi beras nasional sebanyak 6 orang (40\%), dan S2 adalah sebanyak 5 orang (4.17 persen) sedangkan untuk yang mengkonsumsi beras unggul nasional tidak ada. Dari data ini diketahui bahwa sebagian besar masyarakat yang ada di Pekanbaru telah mengenyam pendidikan itu terbukti dari data yang dikumpulkan. Pendidikan ini juga mempengaruhi pengetahuan responden mengenai gizi yang terkandung didalam beras yang dijadikan bahan makanan sehari-hari bagi masyarakat. Berdasarkan peneltian diketahui bahwa tingkat pendidikan S-1 dan S-2 tidak ada yang mengkonsumsi beras unggul nasional.

Tabel 5. Karakteristik Konsumen Berdasarkan Tingkat Pendidikan Konsumen

\begin{tabular}{|c|c|c|c|c|c|}
\hline \multirow{2}{*}{$\begin{array}{l}\mathrm{N} \\
\mathrm{o}\end{array}$} & \multirow{2}{*}{$\begin{array}{c}\text { Tingkat } \\
\text { Pendidikan }\end{array}$} & \multicolumn{2}{|c|}{ Jumlah (Org) } & \multicolumn{2}{|c|}{ Persentase } \\
\hline & & $\begin{array}{l}\text { Var. Unggul } \\
\text { Lokal }\end{array}$ & $\begin{array}{l}\text { Var. Unggul } \\
\text { Nasional }\end{array}$ & $\begin{array}{l}\text { Var. Unggul } \\
\text { Lokal }\end{array}$ & $\begin{array}{c}\text { Var. Unggul } \\
\text { Nasional }\end{array}$ \\
\hline 1 & Tidak Sekolah & 0 & 0 & 0 & 0 \\
\hline 2 & SD & 7 & 0 & 6.67 & 0 \\
\hline 3 & SLTP & 19 & 5 & 19,09 & 33.33 \\
\hline 4 & SLTA & 35 & 4 & 33,33 & 26.67 \\
\hline 5 & Diploma & 9 & 6 & 8.57 & 40 \\
\hline 6 & S-1 & 30 & 0 & 28.57 & 0 \\
\hline 7 & S-2 & 5 & 0 & 4.76 & 0 \\
\hline & Jumlah & 105 & 15 & 100 & 100 \\
\hline
\end{tabular}

Dilihat dari sisi pekerjaan, sebagian besar responden baik responden yang mengkonsumsi beras unggul lokal dan beras unggul nasional adalah ibu rumah tangga sebanyak 38 orang (39.17\%) yang mengonsumsi beras unggul lokal dan 15 orang (100\%) yang mengkosumsi beras unggul nasional, wiraswasta sebanyak 30 orang $(28.57 \%)$, pegawai negeri sebanyak 18 orang $(17.14 \%)$ dan pegawai swasta swasta sebanyak 19 orang $(18.09 \%)$.

43 Analisis Karakteristik Konsumen Beras Di Kecamatan Pekanbaru Kota Kota Pekanbaru 
Apabila dirinci pada masing-masing kelas, terlihat bahwa responden kelas bawah dan kelas atas sebagian besar menjadi ibu rumah tangga. Sedangkan responden kelas menengah sebagian besar adalah pegawai negeri. Alasan menjadi ibu rumah tangga bagi responden kelas bawah berbeda dengan responden kelas atas. Responden kelas bawah cenderung beralasan tidak punya pendidikan yang cukup, sehingga tidak ada alternatif bekerja lainnya selain ibu rumah tangga. Sedangkan alasan responden kelas atas yang tidak bekerja adalah pendapatan keluarga telah cukup, dan alasan lainnya seperti tidak diperbolehkan bekerja oleh suami sehingga bisa lebih konsentrasi melakukan kewajiban sebagai ibu rumah tangga.

Tabel 6. Karakteristik Konsumen Berdasarkan Pekerjaan Responden

\begin{tabular}{|l|l|l|c|c|c|}
\hline \multirow{2}{*}{$\begin{array}{l}\text { N } \\
\text { o }\end{array}$} & \multicolumn{1}{|c|}{ Pekerjaan } & \multicolumn{2}{c|}{ Jumlah (Org) } & \multicolumn{2}{c|}{ Persentase } \\
\cline { 3 - 6 } & $\begin{array}{l}\text { Var. Unggul } \\
\text { Lokal }\end{array}$ & $\begin{array}{l}\text { Var. Unggul } \\
\text { Nasional }\end{array}$ & $\begin{array}{l}\text { Var. Unggul } \\
\text { Lokal }\end{array}$ & $\begin{array}{l}\text { Var. Unggul } \\
\text { Nasional }\end{array}$ \\
\hline 1 & Ibu Rumah Tangga & 38 & 15 & 41.30 & 100 \\
\hline 2 & PNS & 11 & 0 & 11.96 & 0 \\
\hline 3 & Pegawai Swasta & 8 & 0 & 8.69 & 0 \\
\hline 4 & Wiraswasta & 35 & 0 & 38.04 & 0 \\
\hline & Jumlah & 92 & 15 & 100 & 100 \\
\hline
\end{tabular}

Tingkat pendidikan secara tidak langsung juga berpengaruh pada penghasilan per bulan. Ini dikarenakan tingkat pendidikan akan mempengaruhi pekerjaan seseorang. Pendapatan yang dihitung pada penelitian ini adalah pendapatan rata-rata keluarga per bulan yang dihasilkan oleh seluruh anggota keluarga yang telah memiliki pekerjaan. Pendapatan rata-rata keluarga per bulan yaitu pendapatan seluruh anggota keluarga yang bekerja dan dipakai untukpengeluaran keluarga.

Dari Tabel 7 dapat dilihat bahwa pendapatan keluarga yang paling sedikit dalam penelitian ini untuk konsumen yang mengkonsumsi beras unggul lokal adalah sebesar Rp 500.000 yaitu sebanyak 8 orang atau 7,62\%, dan pendapatan masyarakat yang terbanyak untuk konsumsi beras unggul lokal dalam penelitian ini adalah sebesar Rp. 1.500.000, - Rp. 2.999.000, yaitu sebanyak 38 konsumen atau sebesar 36,19\%, dan untuk pendapatan masyarakat lainnya yaitu untuk pendapatan Rp.500.00-Rp. 1.499.000 yaitu sebanyal 16 konsumen atau 15,24\%,

44 Analisis Karakteristik Konsumen Beras Di Kecamatan Pekanbaru Kota Kota Pekanbaru 
pendapatan Rp.3.000.000-Rp. 4.999.000 sebanyak 24 orang atau sebesar 22,86\% dan untuk pendapatan >Rp.5.000.000 sebanyak 19 orang atau sebesar 18,09\%. Untuk konsumen yang mengkonsumsi beras unggul nasional memiliki pendapatan yang paling banyk adalah sebesar Rp. 500.000-Rp. 1.499.000 yaitu sebanyak 10 orang atau sebesar 66,67\% dan untuk pendapatan Rp. 1.500.000-Rp. 2.999.000 yaitu sebanyak 5 orang atau sebesar 33,33\%.

Tabel 7 : Karakteristik Konsumen Berdasarkan Pendapatan Responden

\begin{tabular}{|l|c|c|c|c|}
\hline \multirow{2}{*}{ Pendapatan } & \multicolumn{2}{|c|}{ Jumlah } & \multicolumn{2}{c|}{ Persentase (\%) } \\
\cline { 2 - 5 } & $\begin{array}{l}\text { Var. Unggul } \\
\text { Lokal }\end{array}$ & $\begin{array}{l}\text { Var. Unggul } \\
\text { Nasional }\end{array}$ & $\begin{array}{l}\text { Var. Unggul } \\
\text { Lokal }\end{array}$ & $\begin{array}{l}\text { Var. Unggul } \\
\text { Nasional }\end{array}$ \\
\hline$<$ Rp. 500.00 & 8 & 0 & 7.62 & 0 \\
\hline Rp. 500.000 - 1.499.00 & 16 & 10 & 15,24 & 66.67 \\
\hline Rp. 1.500.000-2.999.000 & 38 & 5 & 36.19 & 33.33 \\
\hline Rp. 3.000.00-4.999.000 & 24 & 0 & 22.86 & 0 \\
\hline$>$ Rp. 5.000.000 & 19 & 0 & 18.09 & 0 \\
\hline \multicolumn{1}{|c|}{ Jumlah } & 105 & 15 & 100 & 100 \\
\hline
\end{tabular}

\section{KESIMPULAN DAN SARAN}

\section{Kesimpulan}

Berdasarkan hasil pembahasan diatas didapatkan beberapa kesimpulan antara lain:

- Karakteristik responden yang dijadikan sampel pada penelitian ini adalah rumah tangga yang mengkonsumsi beras baik beras unggul nasional maupun beras unggul lokal. Rata-rata responden yang mengkonsumsi beras unggul nasional memiliki umur 41 tahun, memiliki pendapatan ratarata Rp.1.679.333,-, pekerjaan respnden semuanya sebagai Ibu rumah tangga, memiliki tangguungan keluarga sebanyak 3 orang, memiliki pendidikan terakhir Diploma. Sedangkan karakteristik konsumen yang mengkonsumsi beras unggul lokal antara lain memiliki umur rata-rata 35 tahun, memiliki tanggngan keluarga sebanyak 3 orang, memiliki pendapatan keluarga sebanyak Rp. 3.274.638,-, memiliki pendidikan terakhir yaitu sarjana.

\section{Saran}


Dari hasil penelitian diketahui bahwa karakteristik konsumen yang membeli beras unggul lokal dibandingkan beras unggul nasional, sehingga untuk dapat meningkatkan konsumsi

\section{DAFTAR PUSTAKA}

Amang, B. dan M. H. Sawit.1999. Kebijakan Beras dan Pangan Nasional.Penerbit Institut pertanian Bogor, Bogor

BPS, 2013. Kota Pekanbaru Dalam Angka.http://www.bps.com. Kecamatan Pekanbaru Dalam Angka.http://www.bps.com.

Balai Pengkajian Teknologi Pertanian (BPTP). 2011. Beras Unggul Lokal Sumatera Barat. http://www.sumbar_bptp@yahoo.com.

Departemen Pertanian, 2011. Varietas Padi Unggul. http://www.deptan.go.id.

Freddy Rangkuti, 2003, Riset Pemasaran. Cetakan Kelima. PT. Gramedia Pustaka Utama. Jakarta. 